\title{
pH Optima in Immune Hemolysis: A Comparison between Guinea Pig and Human Complement *
}

\author{
Stanley Yachnin † and Janet M. Ruthenberg \\ (From the Department of Medicine, University of Chicago, and the Argonne Cancer Research \\ Hospital, $\$$ Chicago, Ill.)
}

Certain in vitro hemolytic systems involving human erythrocytes and human serum function more effectively if hemolysis is allowed to proceed in serum that has been slightly acidified, the optimal $\mathrm{pH}$ being approximately 6.5. Among such " $\mathrm{pH}$ dependent" hemolytic systems are the hemolysis of normal erythrocytes by sera containing high titer cold agglutinins (1); the hemolysis by normal human serum of human erythrocytes whose membranes have been altered by a variety of proteolytic enzymes, chemicals, and viruses (2); the hemolysis of normal human red cells induced by the addition of poly $\mathrm{I}^{1}$ to normal serum (3) ; and the hemolysis of red cells from patients afflicted with $\mathrm{PNH}$ (4). The diagnosis of $\mathrm{PNH}$ usually rests upon what has come to be known as the "acid hemolysis" test $(4,5)$.

The $C^{\prime}$ system clearly plays a role in all these systems, since removal of any one of the four components of $\mathrm{C}^{\prime}$ from serum renders it incapable of participating in these reactions $(1 a, 2,3,6)$. On the other hand, it has been suggested that some other mechanism may be involved in red cell ly-

\footnotetext{
* Submitted for publication July 27, 1964; accepted September 30, 1964.

Supported in part by the Helen and Joseph Regenstein Foundation.

† John and Mary R. Markle Scholar in Academic Medicine.

$\ddagger$ Operated by the University of Chicago for the U. S. Atomic Energy Commission.

1 The following abbreviations are used: $C^{\prime}$, complement; $\mathrm{C}^{\prime} \mathrm{H}_{\mathrm{so}}, 50 \%$ hemolytic unit of complement; $\mathrm{C}^{\prime} 1, \mathrm{C}^{\prime} 2, \mathrm{C}^{\prime} 3$, $C^{\prime} 4$, the first, second, third, or fourth component of complement; C'la, activated first component of complement; R3, serum lacking the third component of complement; $\mathrm{E}$, sheep red cells; $\mathrm{A}$, antibody or amboceptor; EA, sensitized sheep red cells; EAC' ..., sensitized sheep red cells bearing complement components as designated by numerical subscripts; $E^{*}$, red cells irreversibly damaged by the action of complement; hu, human; g.p., guinea pig; PNH, paroxysmal nocturnal hemoglobinuria; poly I, polyinosinic acid.
}

sis, especially in the case of $\mathrm{PNH}$ hemolysis (7, $8,1 b)$. In the hemolytic system dependent on high titer cold agglutinins, Dacie has emphasized that lowering the $\mathrm{pH}$ may favor absorption of hemolysin and so contribute to increased hemolysis (1c). This, however, does not explain the enhancement of hemolysis by acidification in the $\mathrm{PNH}$ or poly I-induced hemolytic systems, where there is no evidence for the participation of red cell antibodies (amboceptor) $(1 d, 3)$.

Should the fact that the hemolytic systems already mentioned have a $\mathrm{pH}$ optimum at 6.5 suggest that their mechanism is in some way different from classical $C^{\prime}$-dependent immune hemolysis and that factors other than $\mathrm{C}^{\prime}$ are involved? Boyd states that the $\mathrm{pH}$ optimum for $\mathrm{C}^{\prime}$ action is 6.3 to 7.8 (9). The first edition of Kabat and Mayer's text quotes earlier work indicating that $\mathrm{C}^{\prime}$ functions more effectively in EA hemolysis at $\mathrm{pH} 7.4$ than at $\mathrm{pH} 6.9$ (10). The second edition, however, states that between $\mathrm{pH} 7.15$ and $8.52, \mathrm{C}^{\prime}$ effectiveness increases with decreasing $\mathrm{pH}$ (11). All these data, however, are from studies using guinea pig serum, and it is difficult to find $\mathrm{pH}$ optimum data dealing with classical EA immune hemolysis where human serum is the source of $\mathbf{C}^{\prime}$. Both Dacie (1e) and Hinz, Picken, and Lepow (12) agree that the optimal $\mathrm{pH}$ for hemolysis of erythrocytes in the $\mathrm{C}^{\prime}$-dependent Donath-Landsteiner antibody hemolytic system is between 7 and 8. Recent studies on the $\mathrm{pH}$ optimum for $\mathrm{C}^{\prime}$-dependent bacteriolysis by human serum have shown that the system functions best at $\mathrm{pH} 8.4$ (13). However, since lysozyme appears to participate in such bacteriolysis, the authors question whether this $\mathrm{pH}$ optimum can fairly be applied to human $\mathrm{C}^{\prime}$ action.

Our study was designed to obtain more definite data on the effect of $\mathrm{pH}$ on human $\mathrm{C}^{\prime}$ action as measured by classical amboceptor-coated sheep 
red cell immune hemolysis. Parallel studies were carried out with guinea pig $\mathrm{C}^{\prime}$, and the results indicate that, in contrast to guinea pig $\mathrm{C}^{\prime}$, human $\mathrm{C}^{\prime}$ is substantially more effective at $\mathrm{pH} 6.5$ than at $\mathrm{pH}$ 7.5. In addition we found that the enhancement of human $\mathrm{C}^{\prime}$-dependent immune hemolysis at $\mathrm{pH} 6.5$ results primarily from a stimulation of $\mathrm{C}^{\prime} 3$.

\section{Methods}

Standard buffer solutions. Stock (five times concentrated) barbital-buffered saline (BBS), $\mathrm{pH} 7.5$, was prepared as described by Kabat and Mayer (11a). Before use it was diluted 1:5 with deionized distilled water, and $\mathrm{Ca}^{++}\left(1.5 \times 10^{-4} \mathrm{M}\right)$ and $\mathrm{Mg}^{++}\left(5 \times 10^{-4} \mathrm{M}\right)$ were added. Solutions of dilute BBS at various $\mathrm{pH}$ 's were prepared by titrating the five times concentrated stock BBS to the desired $\mathrm{pH}$ with $1 \mathrm{~N} \mathrm{NaOH}$ or $\mathrm{HCl}$ before dilution.

Buffer solution containing salts of EDTA. $\mathrm{Na}_{3}-$ HEDTA or $\mathrm{Na}_{2} \mathrm{MgEDTA}^{2}$ was dissolved in water, titrated to the desired $\mathrm{pH}$, and adjusted to $0.15 \mathrm{M}$. $\mathrm{Na}_{2} \mathrm{MgEDT}$ A-BBS contained $1.5 \times 10^{-2} \mathrm{M} \mathrm{Na}_{2} \mathrm{Mg}-$ EDTA plus the necessary amounts of $\mathrm{Ca}^{++}$and $\mathrm{Mg}^{++}$. Since this EDTA salt binds $\mathrm{Ca}^{++}$but not $\mathrm{Mg}^{++}$, serum diluted in $\mathrm{Na}_{2} \mathrm{MgEDTA}-\mathrm{BBS}$ will not support the hemolysis of $\mathrm{EA}$, but will support $\mathrm{EAC}^{\prime}{ }_{1}$ and $\mathrm{EAC}^{\prime}{ }_{1,4}$ lysis. $\mathrm{Na}_{3} \mathrm{HEDTA}-\mathrm{BBS}$ contained $7.5 \times 10^{-3} \mathrm{M} \mathrm{Na}_{3}-$ HEDTA; $\mathrm{Ca}^{++}$and $\mathrm{Mg}^{++}$were omitted. Since $\mathrm{Na}_{3}-$ HEDTA chelates both $\mathrm{Mg}^{++}$and $\mathrm{Ca}^{++}$, serum diluted in this reagent will not support $\mathrm{EA}, \mathrm{EAC}_{1}^{\prime}$, or $\mathrm{EAC}_{1,4}^{\prime}$ lysis, but will hemolyze $\mathrm{EAC}_{1,4,2}^{\prime}$. Serum diluted in BBS was used to assay whole $\mathrm{C}^{\prime}$ activity; $\mathrm{Na}_{2} \mathrm{Mg}-$ EDTA-BBS was used in conjunction with $\mathrm{EAC}^{\prime}{ }_{1}$ to titer the effective combined titer of fluid phase $\mathrm{C}^{\prime} 4, \mathrm{C}^{\prime} 2$, and $\mathrm{C}^{\prime} 3$ and, in conjunction with $\mathrm{EAC}^{\prime}{ }_{1,4}$, to titer $\mathrm{C}^{\prime} 2$ and $C^{\prime} 3$. The effective $C^{\prime} 3$ titer of serum was determined using EAC ${ }_{1,4,2}^{\prime}$ and serum diluted in $\mathrm{Na}_{3}$ HEDTA-BBS.

Serum and serum reagents. Guinea pig blood was collected by cardiac puncture and allowed to stand at room temperature for 4 hours. The serum was then separated by centrifugation, pooled, and frozen in portions at $-85^{\circ} \mathrm{C}$ in a mechanical freezer. Pooled human serum from blood collected by venipuncture was similarly stored. Two separate batches of human $C^{\prime} 1 a$ containing 48 and $37.6 \mathrm{U} \mathrm{C}^{\prime} 1$ esterase, respectively, were prepared by previously described procedures $(14,15)$. Human R3 was prepared by absorption of serum with $2.5 \mathrm{mg}$ zymosan per $\mathrm{ml}$; guinea pig $\mathrm{R} 3$ was prepared using $13 \mathrm{mg}$ zymosan per $\mathrm{ml}(11 b)$. Both R3 preparations were excellent reagents for the preparation of their respective $\mathrm{EAC}^{\prime}{ }_{1, \mathbf{4}, 2}$. Purified $\mathrm{C}^{\prime} 1 a$ and R3 were also stored in portions at $-85^{\circ} \mathrm{C}$.

Sheep red cells and amboceptor. Sterile sheep red blood cells collected in acid citrate dextrose solution and

2 Geigy Industrial Chemicals, Ardsley, N. Y. glycerinated amboceptor were obtained commercially ${ }^{3}$ and kept at $4^{\circ} \mathrm{C}$. Sheep red cells were usually discarded 3 weeks after drawing. A single batch of amboceptor was used throughout these studies.

Preparation of sensitized erythrocytes (EA). The coating of sheep red cells with hemolysin was always carried out at $\mathrm{pH}$ 7.5. The cells were washed three times in BBS and suspended in $\mathrm{Na}_{s}$ HEDTA-BBS to a cell concentration of $2 \times 10^{\circ}$ per ml. An equal volume of hemolysin appropriately diluted in $\mathrm{Na}_{3} \mathrm{HEDTA}-\mathrm{BBS}$ was added and the mixture allowed to stand at room temperature for 15 minutes. The EDTA was used during sensitization to avoid attachment to EA of rabbit $C^{\prime} 1$ sometimes present in commercial glycerinated amboceptors (16). The cells were then washed three times, once in $\mathrm{Na}_{3} \mathrm{HEDTA}-\mathrm{BBS}$ and twice in BBS, and resuspended in BBS to a concentration of either $1 \times 10^{8}$ or $5 \times 10^{8}$ per $\mathrm{ml}$. EA to be tested directly in immune lysis were prepared using a 1:1,000 dilution of amboceptor. EA destined for use in formation of $\mathrm{EAC}^{\prime} \ldots$ were sensitized using a 1:500 dilution of amboceptor.

Preparation of sensitized red cell-complement component intermediates. $\mathrm{EAC}_{1,4,2}^{\prime}$ were prepared by reacting EA with the appropriate R3, and great care was subsequently taken to maintain them at $1^{\circ} \mathrm{C}$ to prevent temperature-dependent decay to $\mathrm{EAC}_{1,4}^{\prime}$ (17). $\mathrm{EAhuC}_{1,4,2}^{\prime}$ were prepared from human $\mathrm{R} 3$ as follows. A measured volume of R3 diluted $1: 20$ in BBS and previously warmed to $37^{\circ} \mathrm{C}\left(1 \mathrm{ml} 1: 20 \mathrm{R} 3 / 5 \times 10^{8} \mathrm{EA}\right)$ was added to a centrifuged button of EA at $37^{\circ}$. The cells were resuspended, and after exactly 60 seconds the mixture was poured into $5 \mathrm{vol}$ of $\mathrm{BBS}$ at $1^{\circ} \mathrm{C}$. The cells were centrifuged, washed three times in cold BBS $\left(1^{\circ}\right)$, and resuspended in BBS $\left(5 \times 10^{3}\right.$ cells per $\left.\mathrm{ml}\right)$. EAg.p. $C_{1,4,2}^{\prime}$ were prepared from guinea pig R3 as follows. One $\mathrm{ml}$ of guinea pig R3 was added to $10 \mathrm{ml}$ $\mathrm{EA}$ in BBS $\left(1 \times 10^{\circ} \mathrm{EA}\right.$ per ml $)$ at $1^{\circ} \mathrm{C}$. After 30 minutes, the cells were centrifuged, washed three times in cold BBS, and finally resuspended in BBS at a cell concentration of $5 \times 10^{8}$ per $\mathrm{ml}$. No more than 30 minutes was allowed to elapse between the preparation of $\mathrm{EAC}_{1,4,2}$ and their use.

$\mathrm{EAC}_{1,4}^{\prime}$ were prepared from $\mathrm{EAC}_{1,4,2}^{\prime}$ by allowing the latter to decay for 90 minutes at $37^{\circ} \mathrm{C}$. The EAC ${ }_{1,4}$ were then washed and resuspended in BBS at a cell concentration of $5 \times 10^{8}$ per ml.

To prepare $\mathrm{EAC}^{\prime}{ }_{1}, .5 \mathrm{ml}$ of an appropriate dilution (determined by pretitration) of purified huC'1a in BBS was added to a cell button of $5 \times 10^{8} \mathrm{EA}$. When $\mathrm{EAhuC}^{\prime}{ }_{1}$ were prepared in bulk, proportionate volumes were employed. After incubation at $37^{\circ}$ for periods of from 3 to 10 minutes, $10 \mathrm{vol}$ of BBS prewarmed to $37^{\circ}$ was added, and the cell suspension was centrifuged for 3 minutes. The $\mathrm{EAhuC}^{\prime}{ }_{1}$ were resuspended in $\mathrm{BBS}\left(37^{\circ} \mathrm{C}\right)$ to a concentration of $5 \times 10^{8}$ per $\mathrm{ml}$ and tested immediately. Maintenance of the EAhuC ${ }_{1}^{\prime}$ at $37^{\circ} \mathrm{C}$ was necessary to prevent loss of huC' ${ }_{1}$ activity, which occurs at lower temperatures (18).

\footnotetext{
${ }^{3}$ Markham Laboratories, Chicago, Ill.
} 


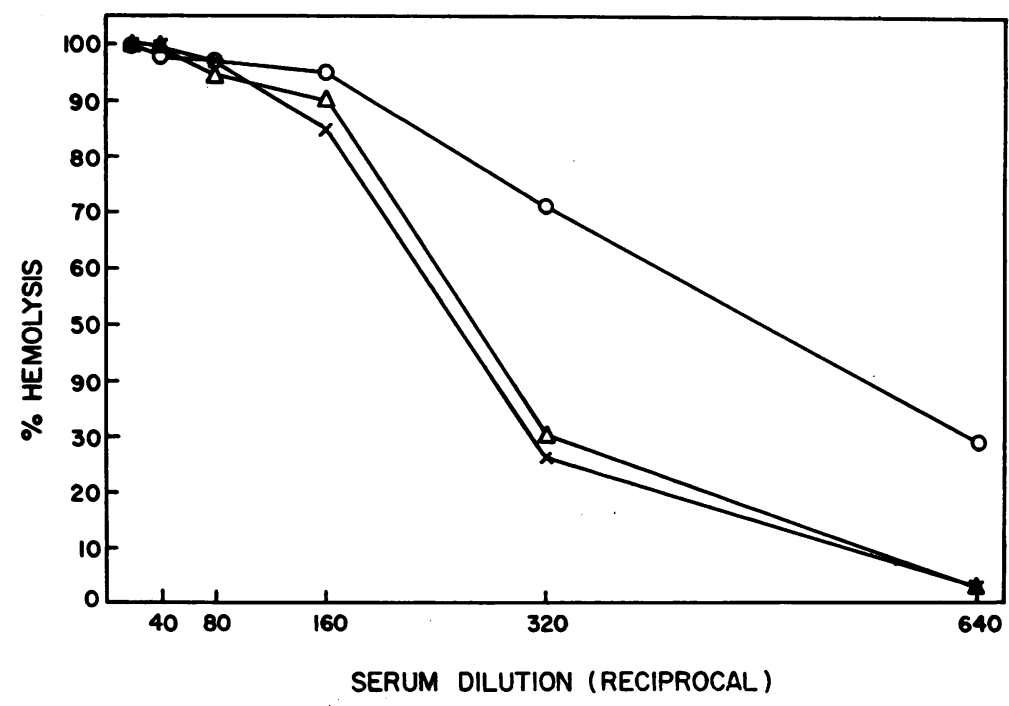

Fig. 1. The efFect of pH EA lysis by humaN $C^{\prime}$. $\bigcirc-\bigcirc, C^{\prime}$ titrated to $\mathrm{pH} 6.5$, diluted in $\mathrm{BBS}, \mathrm{pH} 6.5 ; \times-\times, \mathrm{C}^{\prime}$ titrated to $\mathrm{pH} 6.5$, diluted in BBS, $\mathrm{pH} 7.5 ; \triangle \longrightarrow \triangle, \mathrm{C}^{\prime}$ diluted in $\mathrm{BBS}, \mathrm{pH}$ 7.5. See text, footnote 1 , for abbreviations in all Figures. $\mathrm{BBS}=$ barbital-buffered saline.

The effect of $p H$ on immune hemolysis. The $\mathrm{pH}$ of thawed serum ranged from 7.5 to 7.7. We found that at the dilutions of serum employed, the $\mathrm{pH}$ was effectively controlled by the $\mathrm{pH}$ of the buffered saline used for dilution, so that in most experiments $\mathrm{pH}$ adjustments of $\mathrm{C}^{\prime}$ were an inherent part of the dilution process. In certain experiments, however, the $\mathrm{pH}$ adjustment of serum was initiated directly after thawing. This was done to ensure that altering the $\mathrm{pH}$ of native serum did not irreversibly affect its hemolytic $\mathrm{C}^{\prime}$ potential. Thus, in some experiments serum was adjusted to $\mathrm{pH} 6.5$ with $0.3 \mathrm{~N} \mathrm{HCl}$, and the control serum ( $\mathrm{pH}$ 7.5) was equally diluted with BBS ( $\mathrm{pH} 7.5$ ). The acidified serum was then serially diluted in $\mathrm{pH} 6.5$ buffer (final $\mathrm{pH} 6.5$ ), and $\mathrm{pH} 7.5$ buffer (final $\mathrm{pH} \mathrm{7.5),} \mathrm{and} \mathrm{the} \mathrm{ability} \mathrm{of} \mathrm{these} \mathrm{C}^{\prime}$ dilutions to support immune hemolysis was compared with that of the unacidified serum diluted in $\mathrm{pH} 7.5$ buffer and $\mathrm{pH} 6.5$ buffer. Once it had been determined that preacidification of native serum did not permanently affect its hemolytic $C^{\prime}$ capacity, and that any change in $C^{\prime}$ activity was attributable entirely to the $\mathrm{pH}$ of the dilute $\mathrm{C}^{\prime}$ hemolytic milieu (vide infra), all $\mathrm{pH}$ adjustments of $\mathrm{C}^{\prime}$ reagents were made by dilution in the appropriate buffered saline.

Two basic questions were investigated. 1) What effect does $\mathrm{pH}$ alteration have upon the capacity of $\mathrm{C}^{\prime}$ to support EA or $\mathrm{EAC}^{\prime} \ldots$ hemolysis? The cells were prepared as outlined at a single $\mathrm{pH}$ (7.5), and samples were then subjected to hemolysis in equivalent serial dilutions of $\mathrm{C}^{\prime}$ at varying $\mathrm{pH}$.

2) What effect does $\mathrm{pH}$ alteration have upon the formation of $\mathrm{EAC}^{\prime} \ldots$ ? To eliminate the effects of $\mathrm{pH}$ on the capacity of amboceptor to attach to the red cell, EA formation was always carried out at $\mathrm{pH}$ 7.5. In

TABLE I

The effect of $p H$ on the $C^{\prime} H_{50}$ titer of human and guinea pig complement*

\begin{tabular}{|c|c|c|c|c|c|c|c|c|c|c|c|c|}
\hline \multirow{2}{*}{$\begin{array}{c}\text { Dilution of } C^{\prime} \\
\text { in BBS }\end{array}$} & \multicolumn{6}{|c|}{ Human $\mathrm{C}^{\prime}$ at $\mathrm{pH}$} & \multirow{2}{*}{$\begin{array}{l}\text { Dilution of } \\
\mathrm{C}^{\prime} \text { in } \mathrm{BBS}\end{array}$} & \multicolumn{5}{|c|}{ Guinea pig $\mathrm{C}^{\prime}$ at $\mathrm{pH}$} \\
\hline & 5.5 & 6.0 & 6.5 & 7.0 & 7.5 & 8.0 & & 6.0 & 6.5 & 7.0 & 7.5 & 8.0 \\
\hline & \multicolumn{6}{|c|}{ \% lysis } & & \multicolumn{5}{|c|}{$\%$ lysis } \\
\hline $1: 20$ & 100 & 100 & 100 & 100 & 100 & 100 & $1: 100$ & 100 & 100 & 100 & 100 & 100 \\
\hline $1: 40$ & 100 & 100 & 100 & 100 & 100 & 100 & $1: 200$ & 100 & 100 & 100 & 100 & 100 \\
\hline $1: 80$ & 92 & 100 & 100 & 100 & 97 & 99 & $1: 400$ & 98 & 100 & 100 & 100 & 94 \\
\hline $1: 160$ & 73 & 84 & 90 & 86 & 78 & 48 & $1: 800$ & 82.5 & 85.5 & 80 & 77.6 & 70 \\
\hline $1: 320$ & 32.5 & 38 & 46 & 33 & 22 & 6.5 & $1: 1,600$ & 5.0 & 19 & 24 & 21.6 & 17.5 \\
\hline $1: 640$ & 14 & 16 & 15 & 5.5 & 1.4 & 0 & $1: 3,200$ & 1.8 & 0.9 & 1.7 & 0 & 1.6 \\
\hline $\mathrm{C}^{\prime} \mathrm{H}_{60}$ titer & 237 & 272 & 304 & 274 & 225 & 157 & $\mathrm{C}^{\prime} \mathrm{H}_{60}$ titer & 1,125 & 1,180 & 1,180 & 1,125 & 1,020 \\
\hline Ratio $\frac{\mathrm{C}^{\prime} \mathrm{H}_{60}}{\mathrm{C}^{\prime} \mathrm{H}_{60} \text { at } \mathrm{pH} 7.5}$ & 1.05 & 1.21 & 1.35 & 1.22 & 1.0 & 0.70 & . & 1.00 & 1.05 & 1.05 & 1.00 & 0.907 \\
\hline
\end{tabular}

* See text, footnote 1 , for abbreviations in all Tables. Also, BBS $=$ barbital-buffered saline. 


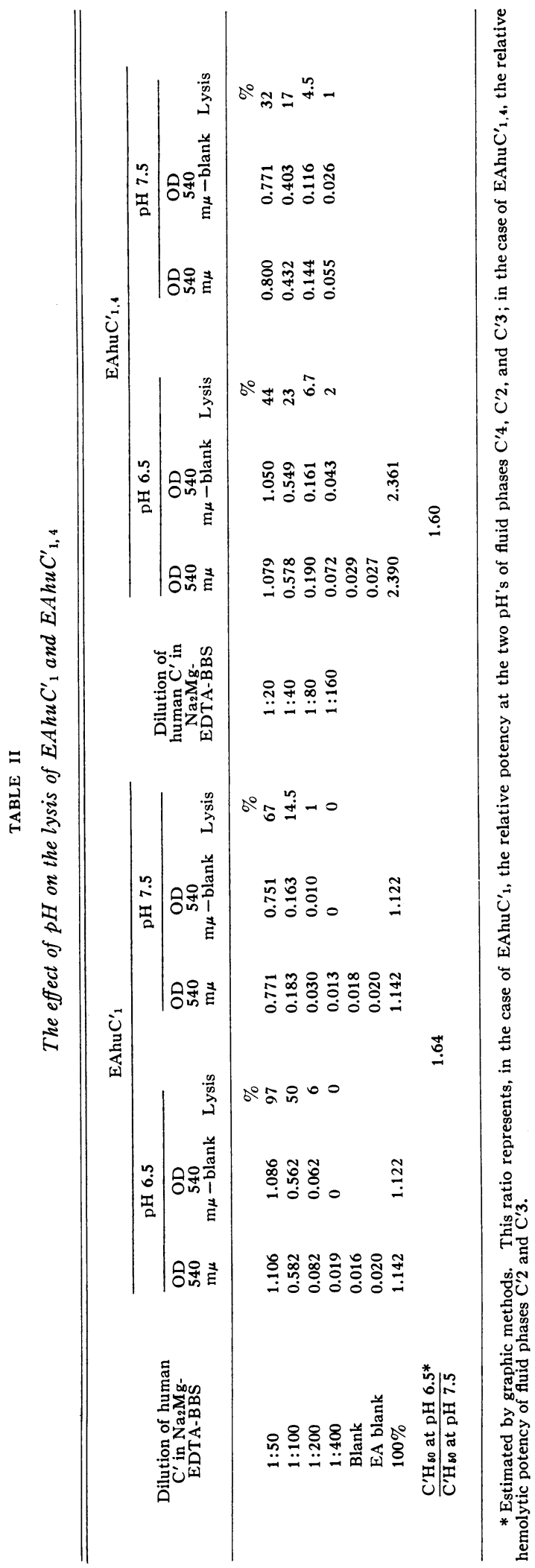

these experiments (involving $\mathrm{EAhuC}^{\prime}{ }_{1}$, and $\mathrm{EAhuC}_{1,4,2}$ ) $\mathrm{EAC}^{\prime} \ldots$ formation was done at varying $\mathrm{pH}$ 's, and lysis was carried out with serial dilutions of $\mathrm{C}^{\prime}$ at a single $\mathrm{pH}$ (7.5). Since excess $\mathrm{C}^{\prime} 1$ was present in substantial amounts during the single wash, EAhuC' ${ }_{1}$ prepared at a given $\mathrm{pH}$ were subjected to washing in buffer of an equivalent $\mathrm{pH}$. However, since excess $\mathrm{R} 3$ was removed in the initial centrifugation following $\mathrm{EAC}_{1,4,2}^{\prime}$ formation, the three washes in these experiments were carried out at $\mathrm{pH}$ 7.5. The effect of $\mathrm{pH}$ on the formation of $\mathrm{EAC}_{1,4}{ }^{4}$ was not investigated, since these cells were prepared from $\mathrm{EAC}^{\prime}{ }_{1,4,2}$ and we assumed that their behavior would parallel that of the parent cell.

All hemolytic tests were carried out by adding $4 \mathrm{ml}$ of the appropriate $\mathrm{C}^{\prime}$ dilution to a thoroughly drained button of $5 \times 10^{8} \mathrm{EA}, \mathrm{EAC}^{\prime}{ }_{1}$, or $\mathrm{EAC}^{\prime}{ }_{1,4,2}$ and incubating the cell suspension at $32^{\circ} \mathrm{C}$ for 60 minutes with occasional mixing. In the experiments with $\mathrm{EAhuC}_{1,4}^{\prime}$, a $1 \times 10^{\circ}$ cell button was employed. Cell blanks in buffer alone at all $\mathrm{pH}$ 's tested were always run. One hundred per cent hemolysis was determined by the addition of $4 \mathrm{ml}$ $0.1 \% \mathrm{Na}_{2} \mathrm{CO}_{3}$ solution to a button of $5 \times 10^{8}$ cells. When $\mathrm{C}^{\prime}$ diluted in $\mathrm{Na}_{2} \mathrm{MgEDTA}-\mathrm{BBS}$ or $\mathrm{Na}_{3}$ HEDTA-BBS was used, an EA blank was always run at the lowest $C^{\prime}$ dilution. Hemolysis was measured by determining the optical density of the supernatant fluid at $540 \mathrm{~m} \mu$. The OD ( $100 \%$ hemolysis) of $5 \times 10^{8}$ cells in a $4-\mathrm{ml}$ vol is approximately 1.3. $\mathrm{C}^{\prime} \mathrm{H}_{50}$ titers of whole $\mathrm{C}^{\prime}$ were determined as outlined by Kabat and Mayer (11c). The proportions of volume, amount of $\mathrm{C}^{\prime}$, and cell concentration were different from those usually employed, and therefore the $\mathrm{C}^{\prime} \mathrm{H}_{50}$ titers are higher than these authors report. Since we were interested primarily in relative titers at various $\mathrm{pH}$ 's, this was not important. In instances where the effects of $\mathrm{pH}$ on the effective cumulative titer of fluid phase $\mathrm{C}^{\prime}$ subcomponents were being assessed with $\mathrm{EAC}^{\prime} \ldots, \mathrm{C}^{\prime} \mathrm{H}_{50}$ titers were approximated by graphic methods employing either logarithmic probability graph paper (titer versus per cent hemolysis) or a log-log plot of titer versus $y / 1-y$ where $y=$ fraction of cells lysed. Although both methods of plotting the data resulted in

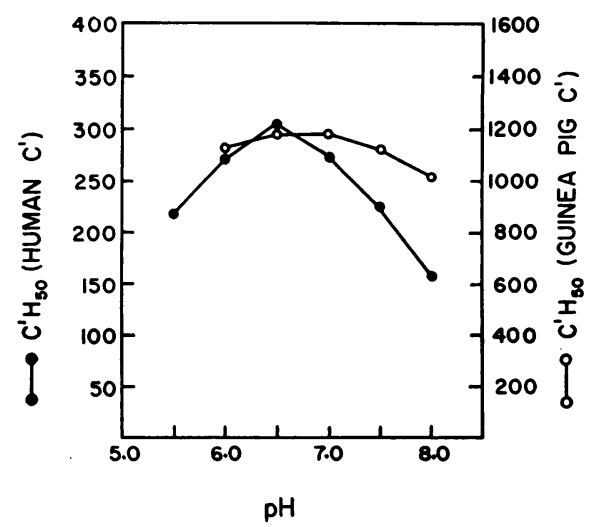

Fig. 2. The efFect of PH ON THE COMPLEMENT TITERS OF HUMAN AND GUINEA PIG SERUM. 


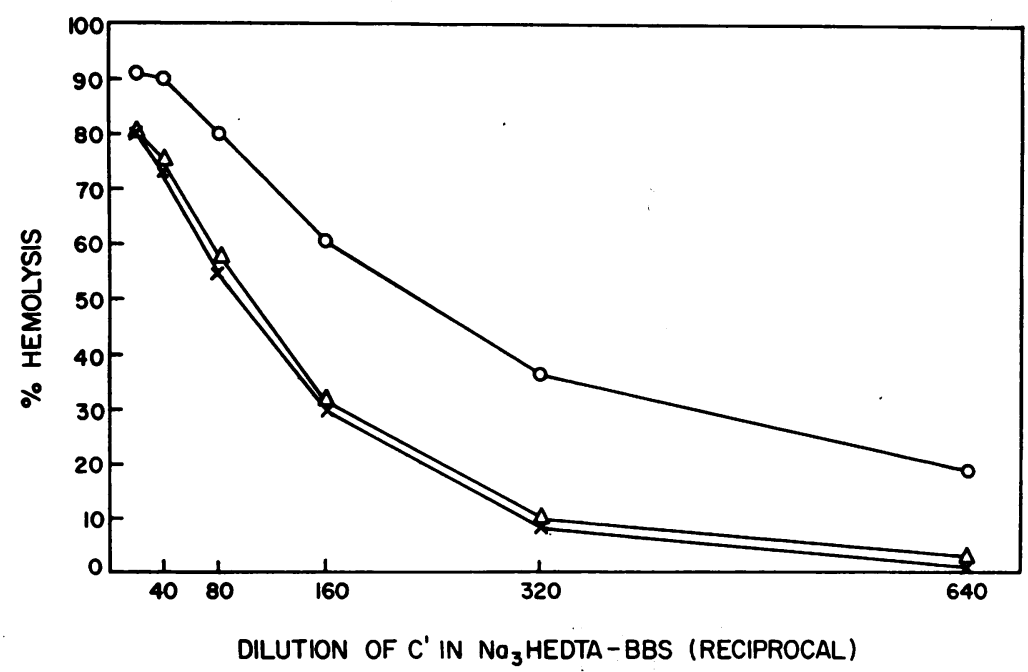

Fig. 3. The efFect of $\mathrm{PH}$ on the ability of human $\mathrm{C}^{\prime}$ diluted in $\mathrm{NA}_{3}$ HEDTA-BBS то Hemolyze EAHUC ${ }_{1,4,2 .} \mathrm{O}-\mathrm{O}, \mathrm{C}^{\prime}$ titrated to $\mathrm{pH}$ 6.5, diluted in $\mathrm{Na}_{3} \mathrm{HEDTA}-\mathrm{BBS}, \mathrm{pH} 6.5 ; \times-\times, \mathrm{C}^{\prime}$ titrated to $\mathrm{pH} 6.5$, diluted in $\mathrm{N}_{\mathrm{s}} \mathrm{HEDTA-BBS}, \mathrm{pH} 7.5 ; \triangle \longrightarrow \triangle, \mathrm{C}^{\prime}$ diluted in $\mathrm{Na}_{3}$ HEDTA-BBS, $\mathrm{pH}$ 7.5.

departure from linearity at the extremes of hemolysis ( 0 to $20 \%$ and 80 to $100 \%$ hemolysis), agreement between these two arbitrary methods was good if the results were based on the values nearest to $50 \%$ hemolysis.

All experiments were performed on at least two separate occasions, and the results obtained were always comparable.

A Zeiss PMQ II spectrophotometer and silica cuvettes with a $1-\mathrm{cm}$ light path were used for all optical density measurements. $\mathrm{pH}$ determinations were made with a Beckman Zeromatic $\mathrm{pH}$ meter.

\section{Results}

The effect of $p H$ on $E A$ and $E A C^{\prime}$. . . lysis. A comparison between the ability of human $\mathrm{C}^{\prime}$ to support EA lysis at $\mathrm{pH} 7.5$ and $\mathrm{pH} 6.5$ is shown in Figure 1. The $\mathrm{C}^{\prime} \mathrm{H}_{50}$ titer of human $\mathrm{C}^{\prime}$ is substantially increased at $\mathrm{pH}$ 6.5. This enhancement is not seen if the human serum serving as a $\mathrm{C}^{\prime}$ source is titrated to $\mathrm{pH} 6.5$ with $\mathrm{HCl}$ and its $\mathrm{pH}$ subsequently raised by dilution in $\mathrm{pH} 7.5 \mathrm{BBS}$.

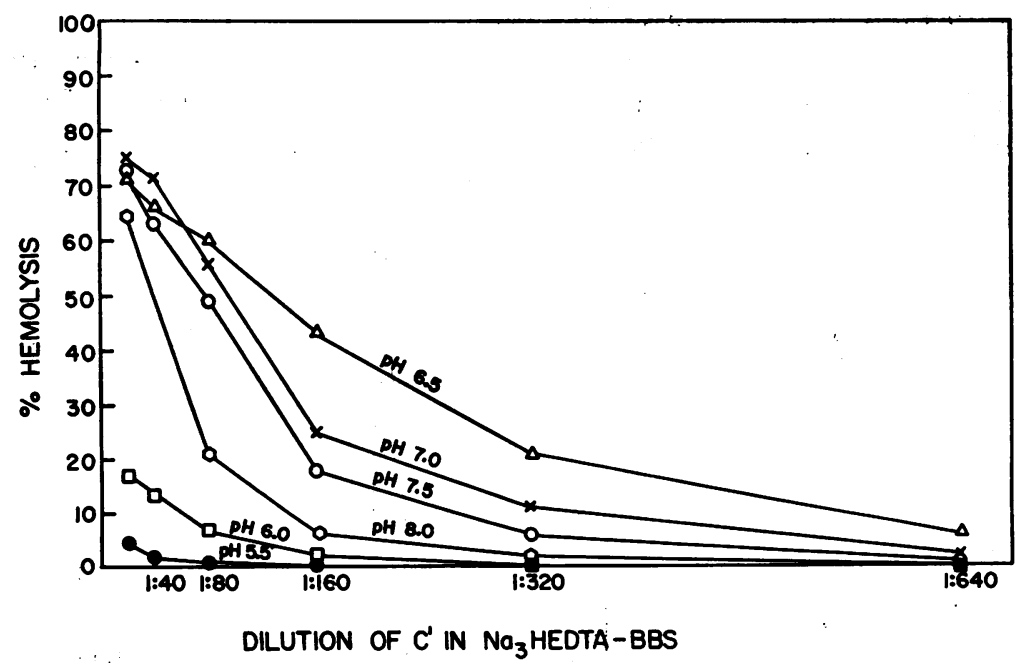

Fig. 4. The efFect of PH ON THE ABILITY OF HUMAN $C^{\prime}$ DILUTEd IN

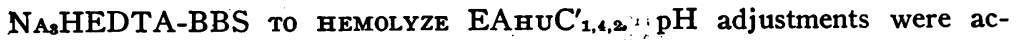
complished by dilution in the appropriate buffer.: 
TABLE III

The effect of $p H$ on the hemolysis of $E A g \cdot p \cdot C_{1,4,2}^{\prime}$

\begin{tabular}{|c|c|c|c|c|c|c|}
\hline \multirow[b]{2}{*}{$\begin{array}{c}\text { Dilution of } \\
\text { guinea pig } \\
C^{\prime} \text { in } \\
\text { NasHEDTA-BBS }\end{array}$} & \multicolumn{3}{|c|}{ pH 6.5} & \multicolumn{3}{|c|}{$\mathrm{pH} 7.5$} \\
\hline & $\begin{array}{l}\text { OD } \\
540 \\
\mathrm{mu}\end{array}$ & $\begin{array}{c}\mathrm{OD} \\
540 \\
\mathrm{~m} \mu-\text { blank }\end{array}$ & Lysis & $\begin{array}{l}\mathrm{OD} \\
540 \\
\mathrm{~m} \mu\end{array}$ & $\begin{array}{c}\text { OD } \\
540 \\
\mathrm{~m} \mu-\text { blank }\end{array}$ & Lysis \\
\hline & & & $\%$ & & & $\%$ \\
\hline $1: 100$ & 1.182 & 1.151 & 91 & 1.177 & 1.153 & 91 \\
\hline $1: 200$ & 1.057 & 1.026 & 81 & 1.017 & 0.993 & 78 \\
\hline $1: 400$ & 0.760 & 0.729 & 58 & 0.761 & 0.737 & 58 \\
\hline $1: 800$ & 0.321 & 0.291 & 23 & 0.354 & 0.330 & 26 \\
\hline $1: 1,600$ & 0.078 & 0.047 & 4 & 0.112 & 0.088 & 7 \\
\hline $1: 3,200$ & 0.041 & 0.010 & 1 & 0.030 & 0.004 & 0 \\
\hline Blank & 0.031 & & & 0.024 & & \\
\hline $100 \%$ & 1.296 & 1.265 & & 1.296 & 1.272 & \\
\hline
\end{tabular}

Thus acidification of whole serum to $\mathrm{pH} 6.5$ has no permanent or irreversible effects upon whole $\mathrm{C}^{\prime}$ activity. More extensive data on the effects of $\mathrm{pH}$ on human $\mathrm{C}^{\prime}$ activity in EA lysis, together with similar observations made on guinea pig $\mathrm{C}^{\prime}$, are shown in Table I and Figure 2. Our results concerning the effect of $\mathrm{pH}$ on the $\mathrm{C}^{\prime}$ titer of guinea pig serum are in substantial agreement with those of Kabat and Mayer (11). There is a slight but definite increase in guinea pig $\mathrm{C}^{\prime}$ potency with decreasing $\mathrm{pH}$, a broad optimum being reached between $\mathrm{pH} 6.5$ and 7.0. The effect of decreasing $\mathrm{pH}$ on human $\mathrm{C}^{\prime}$ potency is, in contrast, much greater, with a narrower optimum, at about $\mathrm{pH} 6.5$.

Having demonstrated substantial enhancement of hemolytic human $\mathrm{C}^{\prime}$ potency at $\mathrm{pH} 6.5$, we studied the effect of $\mathrm{pH}$ on the lysis of various $\mathrm{EAC}^{\prime}$ ... in the hope of determining which of the intermediate stages in immune hemolysis were most affected by such $\mathrm{pH}$ alterations. The data in Table II illustrate the effect of $\mathrm{pH}$ on the hemolysis of $\mathrm{EAhuC}^{\prime}{ }_{1}$ and $\mathrm{EAhuC}^{\prime}{ }_{1,4}$ in human $\mathrm{C}^{\prime}$ diluted in $\mathrm{Na}_{2} \mathrm{MgEDTA}-\mathrm{BBS}$. Since both of these $\mathrm{C}^{\prime}$ component-EA intermediates hemolyze more effectively at $\mathrm{pH} 6.5$, and since both are equally enhanced to approximately the same degree as noted earlier with EA lysis, we presumed that the stimulatory effect of $\mathrm{pH}$ reduction depends primarily upon enhancement of either $\mathrm{C}^{\prime} 2$ or $\mathrm{C}^{\prime} 3$ or both. From the results shown in Figures 3 and 4 we concluded that $\mathrm{pH}$ alteration affects primarily the last stage in immune hemolysis, namely, the reaction $\mathrm{EAhuC}_{1,4,2}^{\prime}+\mathrm{huC}^{\prime} 3 \rightarrow \mathrm{E}^{*}$. It is apparent again, in a fashion analogous to EA lysis, that acidification of whole serum to $\mathrm{pH} 6.5$, followed by dilution at $\mathrm{pH} 7.5$, does not permanently alter the effective $C^{\prime} 3$ titer of serum. By comparison with EA lysis, $\mathrm{EAhuC}_{1,4,2}^{\prime}$ hemolysis diminishes rather sharply as the $\mathrm{pH}$ is lowered from the optimum at 6.5. In contrast to human $\mathrm{C}^{\prime}$, the reaction EAg.p. $\mathrm{C}_{1,4,2}^{\prime}+$ g.p. $\mathrm{C}^{\prime} 3 \rightarrow \mathrm{E}^{*}$ is

TABLE IV

Comparison of the hemolytic potency of human $C^{\prime}$ and $C^{\prime}$ subcomponents at pH 6.5 and $p H 7.5$

\begin{tabular}{|c|c|c|c|c|c|}
\hline \multirow[b]{2}{*}{ Cell type } & \multirow{2}{*}{$\begin{array}{c}\text { Experi- } \\
\text { ment } \\
\text { no. }\end{array}$} & \multicolumn{2}{|c|}{$\mathrm{C}^{\prime} \mathrm{H}_{50}$} & \multirow{2}{*}{$\frac{\mathrm{C}^{\prime} \mathrm{H}_{50} \text { at } \mathrm{pH} 6.5}{\mathrm{C}^{\prime} \mathrm{H}_{50} \text { at } \mathrm{pH} 7.5}$} & \multirow{2}{*}{$\frac{\mathrm{C}^{\prime} \mathrm{H}_{50} \text { at } \mathrm{pH} 6.5}{\mathrm{C}^{\prime} \mathrm{H}_{50} \text { at } \mathrm{pH}} 7.5$} \\
\hline & & pH 6.5 & $\mathrm{pH} 7.5$ & & \\
\hline \multirow[t]{4}{*}{ I. EA } & 1 & 391 & 294 & 1.33 & \multirow{6}{*}{1.40} \\
\hline & 2 & 445 & 265 & 1.68 & \\
\hline & 3 & 304 & 223 & 1.35 & \\
\hline & 4 & 435 & 355 & 1.22 & \\
\hline II. $\mathrm{EAhuC}^{\prime}{ }_{1}$ & 1 & $100 *$ & $61^{*}$ & $1.64^{*}$ & \\
\hline III. EAhuC ${ }_{1,4}^{\prime}$ & 1 & $16.8^{*}$ & $10.5^{*}$ & $1.60^{*}$ & \\
\hline \multirow[t]{3}{*}{ IV. EAhuC ${ }_{1,4,2}^{\prime}$} & 1 & $219 *$ & 93* & $2.35^{*}$ & \multirow{3}{*}{$1.80^{*}$} \\
\hline & 2 & $120 *$ & $77 *$ & $1.56^{*}$ & \\
\hline & 3 & $178 *$ & $119 *$ & $1.49^{*}$ & \\
\hline
\end{tabular}

* Estimated by graphic methods. The ratio represents, in the case of EAhuC' ${ }_{1}$, the relative potency at the two $\mathrm{pH}^{\prime} \mathrm{s}$ of fluid phases $C^{\prime} 4, C^{\prime} 2$, and $C^{\prime} 3$; in the case of $E A h u C_{1,4}^{\prime}$, the relative hemolytic potency of fluid phases $C^{\prime} 2$ and $C^{\prime} 3$; in the case of $\mathrm{EAhuC}^{\prime}{ }_{1,4,2}$, the relative hemolytic potency of fluid phase $\mathrm{C}^{\prime} 3$. 
TABLE V

The effect of $p H$ on the formation of $E A h u C^{\prime}{ }_{1}$

\begin{tabular}{|c|c|c|c|c|c|c|}
\hline \multirow[b]{3}{*}{$\begin{array}{l}\text { Dilution of human } C^{\prime} \\
\text { in Na2MgEDTA-B BS }\end{array}$} & \multicolumn{6}{|c|}{ EAhuC ${ }_{1}^{\prime}$ formed at $\mathrm{pH}$} \\
\hline & \multicolumn{3}{|c|}{6.5} & \multicolumn{3}{|c|}{7.5} \\
\hline & $\begin{array}{l}\text { OD } \\
540 \\
\mathrm{~m} \mu\end{array}$ & $\begin{array}{c}\text { OD } \\
540 \\
\text { m } \mu \text {-blank }\end{array}$ & Lysis & $\begin{array}{l}\text { OD } \\
540 \\
\mathrm{~m} \mu\end{array}$ & $\begin{array}{c}\text { OD } \\
540 \\
\mathrm{~m} \mu \text {-blank }\end{array}$ & Lysis \\
\hline $\begin{array}{ll}\text { Experiment } & \text { I } 1: 50 \\
& \text { Blank } \\
& 100 \%\end{array}$ & $\begin{array}{l}0.440 \\
0.025 \\
1.153\end{array}$ & $\begin{array}{c}0.415 \\
0 \\
1.128\end{array}$ & $\begin{array}{c}\% \\
36\end{array}$ & $\begin{array}{l}0.487 \\
0.025 \\
1.156\end{array}$ & $\begin{array}{c}0.462 \\
0 \\
1.131\end{array}$ & $\begin{array}{c}\% \\
40.7\end{array}$ \\
\hline $\begin{aligned} & \text { Experiment II } 1: 50 \\
& 1: 100 \\
& 1: 200 \\
& \text { Blank } \\
& 100 \%\end{aligned}$ & $\begin{array}{l}0.592 \\
0.183 \\
0.038 \\
0.020 \\
1.153\end{array}$ & $\begin{array}{c}0.572 \\
0.163 \\
0.018 \\
0 \\
1.133\end{array}$ & $\begin{array}{c}50.4 \\
14.4 \\
2\end{array}$ & $\begin{array}{l}0.665 \\
0.189 \\
0.032 \\
0.020 \\
1.126\end{array}$ & $\begin{array}{c}0.645 \\
0.169 \\
0.012 \\
0 \\
1.106\end{array}$ & $\begin{array}{c}58.4 \\
15.3 \\
1\end{array}$ \\
\hline
\end{tabular}

not affected by altering the $\mathrm{pH}$ from 7.5 to 6.5 (Table III). A summary of the effects of $\mathrm{pH}$ alteration from 7.5 to 6.5 on the relative hemolytic potency of human fluid phase $\mathrm{C}^{\prime}$ components at various stages in immune lysis is presented in Table IV.

The effect of $p H$ on the formation of $E A C^{\prime}$. . . To confirm the above conclusion that $\mathrm{pH}$ alteration largely affects the reaction $\mathrm{EAhuC}_{1,4,2}^{\prime}+$ $h u C^{\prime} 3 \rightarrow E^{*}$, the effect of $\mathrm{pH}$ upon the formation of various $\mathrm{EAC}^{\prime}$... intermediates in immune hemolysis was analyzed. We reasoned that if these conclusions were correct, the formation of $\mathrm{EAC}^{\prime}{ }_{1}$ and $\mathrm{EAC}^{\prime}{ }_{1,4,2}$ (and by implication $\mathrm{EAC}^{\prime}{ }_{1,4}$ ) should not be enhanced by lowering $\mathrm{pH}$ from 7.5 to 6.5. These experiments (Tables V and VI) bear out the conclusions drawn earlier; EAhuC' ${ }_{1}$ formation is, if anything, slightly inhibited at $\mathrm{pH}$ 6.5 ; $\mathrm{EAhuC}_{1,4,2}^{\prime}$ formation is not affected. In relation to the latter experiment, it is imperative to use an R3 devoid of even small amounts of $\mathrm{C}^{\prime} 3$; otherwise there is substantial $\mathrm{E}^{*}$ formation at $\mathrm{pH}$ 6.5 , with the result that much hemolysis occurs during preparation of the cells even though $\mathrm{EAhuC}_{\mathbf{1}, \mathbf{4}, 2}$ formation with the same $\mathrm{R} 3$ may proceed satisfactorily at $\mathrm{pH}$ 7.5. This observation, although largely of nuisance value in terms of experimental technique, also indicates the primary role of $\mathrm{C}^{\prime} 3$ in the enhancement of human $\mathrm{C}^{\prime}$ action at $\mathrm{pH} 6.5$.

The effect of $p H$ on the decay of $E A C^{\prime}{ }_{1,4,2}$. Although the data so far presented leave little doubt that $\mathrm{pH}$ reduction from 7.5 to 6.5 selectively enhances the last stage in immune hemolysis, the same result could be obtained by two different mechanisms. The over-all hemolytic titer of $\mathrm{C}^{\prime}$ is recognized to depend primarily upon the balance achieved between the decay of $\mathrm{EAC}_{1,4,2}^{\prime}$ to $\mathrm{EAC}_{1,4}^{\prime}$ and the conversion of $\mathrm{EAC}_{1,4,2}^{\prime}$ to $\mathrm{E}^{*}$ by the action of $\mathrm{C}^{\prime} 3$ (19). $\mathrm{pH}$ reduction might result in en-

TABLE VI

The effect of $p H$ on the formation of $E A h u C_{1,4,2}^{\prime}$

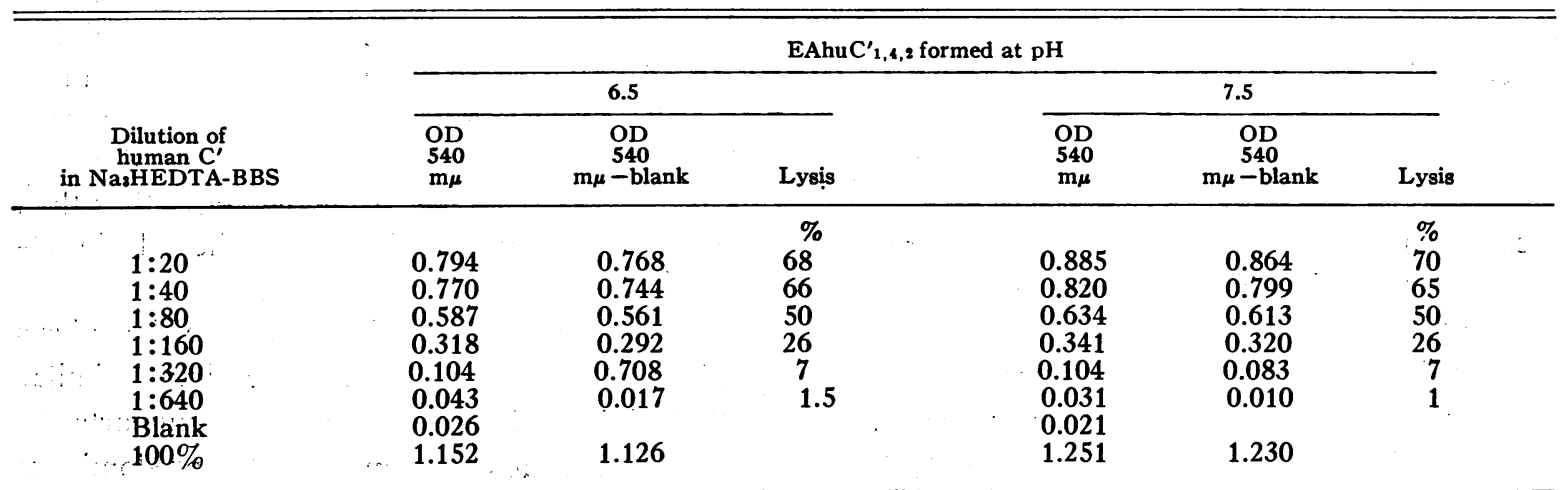




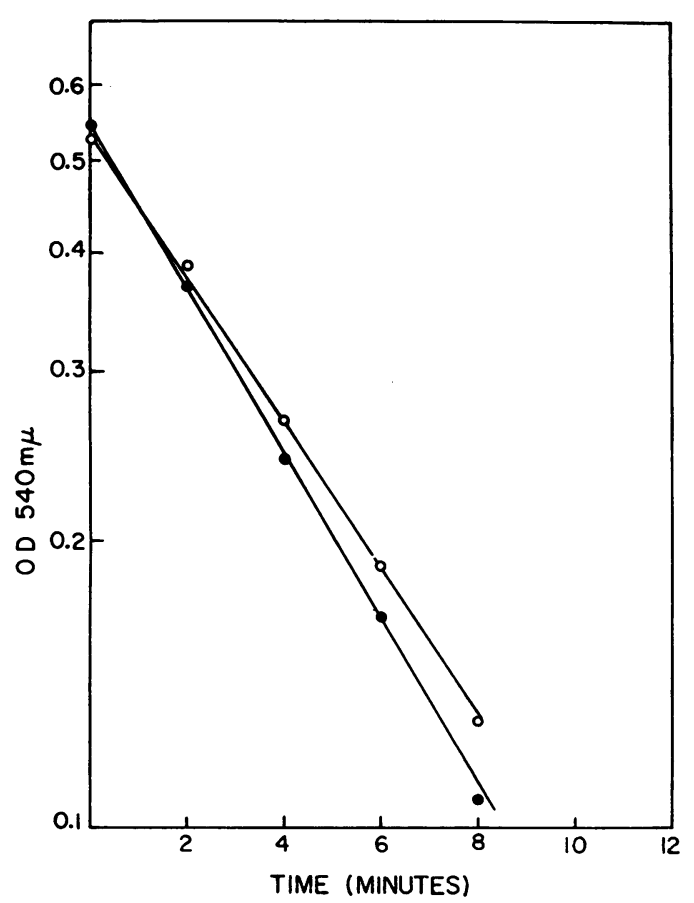

Fig. 5. THE EFFECT OF PH ON THE DECAY OF $\mathrm{EAHuC}_{1,4,2}^{\prime}$ то EAнuC ${ }_{1,4}^{\prime}$. $\mathrm{EAhuC}_{1,4,2}$ decayed at $\mathrm{pH} 7.5 ; \mathrm{O}, \mathrm{EAhuC}^{\prime}{ }_{1,4,2}$ decayed at $\mathrm{pH} 6.5$.

hancement of $\mathrm{C}^{\prime} 3$ activity, but the same result would be achieved if lowering the $\mathrm{pH}$ diminished the rate at which $\mathrm{EAhuC}_{1,4,2}^{\prime}$ decayed to $\mathrm{EAhuC}_{1,4}$. This latter possibility was tested by the following experiment: Suspensions of EAhuC $_{1,4,2}^{\prime}\left(5 \times 10^{8}\right.$ cells per $\left.\mathrm{ml}\right)$ in $\mathrm{Na}_{3}$ HEDTA-BBS at both $\mathrm{pH} 6.5$ and $\mathrm{pH} 7.5$ were placed in a water bath at $37^{\circ} \mathrm{C}$. When the temperature within the suspensions reached $37^{\circ}, 1-\mathrm{ml}$ samples were removed at measured time intervals and added to $4 \mathrm{ml}$ of a $1: 40$ dilution of human serum in $\mathrm{Na}_{3} \mathrm{HEDTA}-\mathrm{BBS}, \mathrm{pH}$ 7.5. These tubes were mixed and incubated at $32^{\circ}$ for 60 minutes to determine residual $\mathrm{EAhuC}_{\mathbf{1 , 4 , 2}}^{\prime}$ activity. The results are shown in Figure 5. The rate of the temperature-dependent decay reaction $\mathrm{EAhuC}_{1,4,2}^{\prime} \rightarrow \mathrm{EAhuC}_{1,4}^{\prime}$ is similar at both $\mathrm{pH}$ 7.5 and $\mathrm{pH} 6.5\left(\mathrm{t}_{\frac{1}{2}}=3.5\right.$ and 4.05 minutes, respectively). The slight reduction of the rate of decay seen at $\mathrm{pH} 6.5$ is not sufficient to account for the degree of enhancement seen in $\mathrm{EAhuC}_{1,4,2}^{\prime}$ lysis at this $\mathrm{pH}$. Thus it would seem that most of the enhancement in immune hemolysis at $\mathrm{pH} 6.5$ is attributable to stimulation of $\mathrm{C}^{\prime} 3$ activity.

\section{Discussion}

The present data indicate that those human $\mathrm{C}^{\prime}$-dependent hemolytic systems that function best at $\mathrm{pH} 6.5$ are not different in this respect from classical inmune hemolysis. Indeed, it might be said that a hemolytic system involving human $\mathrm{C}^{\prime}$ that functions better at $\mathrm{pH}$ 's alkaline to 7 , such as the Donath-Landsteiner hemolytic system, is the exception; perhaps in this instance the limiting factor is hemolysin attachment, which is favored by a more alkaline $\mathrm{pH}$. In the present studies, red cell sensitization was always performed at $\mathrm{pH}$ 7.5 , regardless of the $\mathrm{pH}$ at which hemolysis was carried out, and variations in the effect of $\mathrm{pH}$ on hemolysin attachment were avoided. However, it might still be argued that lowering of $\mathrm{pH}$ diminishes the rate at which hemolysin elutes from $\mathrm{EA}$, and thereby promotes the action of $\mathrm{C}^{\prime}$ at $\mathrm{pH}$ 6.5. Such an argument is difficult to refute on theoretical grounds, since hemolysin is known to elute from EA and to transfer from cell to cell $(11 d)$, and $C^{\prime}$ titer in a limited $C^{\prime}$ system can be increased by increasing the number of sensitized sites on the red cell membrane (20). If this were the mechanism operating to increase human $\mathrm{C}^{\prime}$ effectiveness at $\mathrm{pH}$ 6.5, then a similar degree of enhancement would be expected regardless of the $\mathrm{C}^{\prime}$ source. That guinea pig $\mathrm{C}^{\prime}$ is in fact not enhanced to the same extent by $\mathrm{pH}$ alteration is therefore a strong point in favor of a direct action of $\mathrm{pH}$ alteration on human $\mathrm{C}^{\prime}$ effectiveness. In addition, if $\mathrm{pH}$ reduction resulted in tighter binding of $\mathrm{A}$ to $\mathrm{E}$, then the enhancing effects of $\mathrm{pH}$ reduction on human $\mathrm{C}^{\prime}$-dependent hemolysis should be obvious during the early phases of immune hemolysis. Formation of $\mathrm{EAhuC}^{\prime}{ }_{1}$ and $\mathrm{EAhuC}_{1,4,2}$, however, was not increased by $\mathrm{pH}$ reduction. The ability of $\mathrm{pH}$ reduction to enhance the hemolysis of normal human red cells by high titer cold agglutinins, or of artifically altered red cells by human sera containing heterospecific antibodies, can thus be viewed as a $C^{\prime}$-mediated phenomenon, rather than one brought about by increasing hemolysin attachment.

Recognition that classical immune hemolysis produced by human $\mathrm{C}^{\prime}$ has a $\mathrm{pH}$ optimum similar to that of the $\mathrm{PNH}$ hemolytic system supports the argument that the $\mathrm{C}^{\prime}$ system plays the predominant 
role in in vitro $\mathrm{PNH}$ red cell lysis. Immune hemolysis and poly I-induced hemolysis of normal red cells have recently been shown to proceed in the absence of $\mathrm{Ca}^{++}$, provided that $\mathrm{Mg}^{++}$is supplied and whole human serum is used as the $\mathrm{C}^{\prime}$ source $(3,21) ; \mathrm{PNH}$ hemolysis also displays an absolute requirement for $\mathrm{Mg}^{++}$but not for $\mathrm{Ca}^{++}$ (6). Thus the PNH hemolytic system resembles other human $\mathrm{C}^{\prime}$-dependent hemolytic systems not only in its $\mathrm{pH}$ optimum, but also in divalent cation requirements. The enhancement of immune red cell lysis and $\mathrm{PNH}$ hemolysis produced by reduction of serum $\mathrm{pH}$ to 6.5 are similar in that both phenomena are reversible; restoration of serum $\mathrm{pH}$ to 7.5 results in loss of the stimulatory effect and the return of serum hemolytic potency to the original level (22).

We have recently shown that substances usually considered to be anticomplementary, such as polyinosinic acid, streptokinase, and aggregated $\gamma$-globulin, can all cause enhancement of $\mathrm{PNH}$ red cell hemolysis in vitro when added to acidified human serum $(3,22)$; these three agents are known to function as activators of $\mathrm{C}^{\prime} 1(23-26)$. Furthermore, addition of purified $C^{\prime} 1 \mathrm{a}$ or $\mathrm{C}^{\prime} 1$ esterase to serum can induce the same stimulation of $\mathrm{PNH}$ hemolysis (22). Careful study of all these materials has revealed a striking similarity in the kinetics of their interaction with serum in relation to PNH hemolysis. Therefore, we have suggested that these substances via $C^{\prime} 1 a$, or $C^{\prime} 1 a$ itself, activate fluid phase $\mathrm{C}^{\prime} 2$, which in turn is responsible for the generation of fluid phase $C^{\prime} 3$ hemolytic activity; it is presumably a late-acting $\mathrm{C}^{\prime} 3$ subcomponent(s) that ultimately injures the red cell membrane $(3,27)$. Since the $\mathrm{PNH}$ red cell lacks an antibody coat to localize the process of $\mathrm{C}^{\prime}$ activation at the cell membrane, its destruction depends upon random hits from activated fluid phase $C^{\prime} 3$ subcomponents (3). The importance of late-acting $C^{\prime} 3$ subcomponents in relation to $\mathrm{PNH}$ hemolysis is attested to by the recent observations of Rosen and of Jenkins. In preliminary experiments Rosen has observed that purified $\beta_{1 \mathrm{C}}$-globulin can attach to $\mathrm{PNH}$ red cells directly without the mediation of other fluid phase $\mathrm{C}^{\prime}$ components (28). Jenkins, who has found $\mathrm{C}^{\prime}$ components coating those $\mathrm{PNH}$ red cells resistant to in vitro acid hemolysis (29), has noted that such cells react strongly and con- sistently with anti- $\beta_{1}$-globulin (30) (anti-C'3), but weakly and less consistently with anti- $\beta_{1 \mathbf{C}^{-}}$ globulin (31) (anti-C'4) (32). We have postulated that $\mathrm{PNH}$ hemolysis is, in a sense, a threshold phenomenon that depends upon an intrinsic low grade process of activation of fluid phase lateacting $\mathrm{C}^{\prime}$ components in serum (3).

In view of the foregoing discussion, it is of great interest to find that $\mathrm{pH}$ alterations of serum from 7.5 to 6.5 predominantly enhance the hemolytic function of $\mathrm{C}^{\prime} 3$. If one examines the data in Figures 1 and 3, he is struck by the fact that in immune hemolysis, given the proper conditions, the degree of hemolysis can be altered by $\mathrm{pH}$ change to the same extent as is commonly observed in $\mathrm{PNH}$ hemolysis. Thus in a $1: 160 \mathrm{di}-$ lution of human $\mathrm{C}^{\prime} 3, \mathrm{EAhuC}^{\prime, 4,2}$ show $9.5 \%$ hemolysis at $\mathrm{pH} 7.5$ as compared with $37 \%$ hemolysis at $\mathrm{pH} 6.5$ (Figure 3). Similarly, in a $1: 640$ dilution of whole human $\mathrm{C}^{\prime}, \mathrm{EA}$ display $3 \%$ lysis at $\mathrm{pH} 7.5$ compared with $29 \%$ hemolysis at $\mathrm{pH} 6.5$ (Figure 1). $\mathrm{PNH}$ hemolysis in vitro results in no diminution of serum $\mathrm{C}^{\prime}$ titer as subsequently measured by immune hemolysis, and may thus be considered to involve only such small amounts of active $C^{\prime}$ material as are represented by serum dilutions in the range mentioned above (33).

\section{Summary}

The $\mathrm{pH}$ optima of the immune lysis of sensitized sheep red cells by human and guinea pig complement have been investigated. Both human and guinea pig complement function best at $\mathrm{pH} 6.5$, but human complement is more sensitive to $\mathrm{pH}$ alteration. Study of the effects of $\mathrm{pH}$ alteration upon the formation and lysis of sensitized red cell-complement component intermediates has demonstrated that the enhanced potency of human complement action at $\mathrm{pH} 6.5$ results from a stimulation of the third complement component. The significance of these observations relative to certain " $\mathrm{pH}$-dependent" human hemolytic systems is discussed.

\section{References}

1. Dacie, J. V. The haemolytic anemias, congenital and acquired. London, J. and A. Churchill, 1954, p. 250 ; (a) p. 257 ; (b) p. 428 ; (c) p. 251 ; (d) p. 433 ; (e) p. 279 . 
2. Yachnin, S., M. T. Laforet, and F. H. Gardner. $\mathrm{pH}$ dependent hemolytic systems. I. Their relationship to paroxysmal nocturnal hemoglobinuria. Blood 1961, 17, 83.

3. Yachnin, S., and J. M. Ruthenberg. The initiation and enhancement of human red cell lysis by an activator of the first component of complement and by first component esterase; studies using normal red cells and red cells from patients with paroxysmal nocturnal hemoglobinuria. J. clin. Invest. 1965, 44, in press.

4. Ham, T. H. Chronic hemolytic anemia with paroxysmal nocturnal hemoglobinuria: study of the mechanism. of hemolysis in relation to acidbase equilibrium. New Engl. J. Med. 1937, 217, 915.

5. Dacie, J. V., M. C. G. Israëls, and J. F. Wilkinson. Paroxysmal nocturnal hæmoglobinuria of the Marchiafava type. Lancet 1938, 1, 479.

6. Hinz, C. F., Jr., W. S. Jordan, Jr., and L. Pillemer. The properdin system and immunity. IV. The hemolysis of erythrocytes from patients with paroxysmal nocturnal hemoglobinuria. J. clin. Invest. $1956,35,453$.

7. Wagley, P. F., and M. D. Hickey. Susceptibility of red cells and serum factor in the mechanism of hemolysis in paroxysmal nocturnal hemoglobinuria (abstract). J. clin. Invest. 1948, 27, 559.

8. Crosby, W. H. Paroxysmal nocturnal hemoglobinuria. Plasma factors of the hemolytic system. Blood 1953, 8, 444.

9. Boyd, W. C. Fundamentals of Immunology, 3rd ed. New York, Interscience, 1956, p. 373.

10. Kabat, E. A., and M. M. Mayer. Experimental Immunochemistry, 1st ed. Springfield, Ill., Charles C Thomas, 1948, p. 106.

11. Kabat, E. A., and M. M. Mayer. Experimental Immunochemistry, 2nd ed. Springfield, Ill., Charles C Thomas, 1961, p. 148; (a) p. 149; (b) p. 163 ; (c) p. 135 ; (d) p. 141.

12. Hinz, C. F., Jr., M. E. Picken, and I. H. Lepow. Studies on immune hemolysis. I. The kinetics of the Donath-Landsteiner reaction and the requirement for complement in the reaction. J. exp. Med. 1961, 113, 177.

13. Wardlaw, A. C. The complement-dependent bacteriolytic activity of normal human serum. I. The effect of $\mathrm{pH}$ and ionic strength and the role of lysozyme. J. exp. Med. 1962, 115, 1231.

14. Lepow, I. H., O. D. Ratnoff, F. S. Rosen, and L. Pillemer. Observations on a pro-esterase associated with partially purified first component of human complement (C'1). Proc. Soc. exp. Biol. (N. Y.) 1956, 92, 32.

15. Levy, L. R., and I. H. Lepow. Assay and properties of serum inhibitor of $\mathrm{C}^{\prime} 1$-esterase. Proc. Soc. exp. Biol. (N. Y.) 1959, 101, 608.

16. DeLooze, L. L., A. Ransby, and M. A. Leon. Activity of $C^{\prime} 1$ in rabbit antisheep hemolysin. Proc. Soc. exp. Biol. (N. Y.) 1962, 109, 393.
17. Mayer, M. M., L. Levine, H. J. Rapp, and A. A. Marucci. Kinetic studies on immune hemolysis. VII. Decay of $\mathrm{EAC}^{\prime}{ }_{142}$, fixation of $\mathrm{C}^{\prime} 3$, and other factors influencing the hemolytic action of complement. J. Immunol. 1954, 73, 443.

18. Lepow, I. H., G. B. Naff, E. W. Todd, J. Pensky, and C. F. Hinz, Jr. Chromatographic resolution of the first component of human complement into three activities. J. exp. Med. 1963, 117, 983.

19. Austen, K. F., and Z. A. Cohn. Contribution of serum and cellular factors in host defense mechanisms. New Engl. J. Med. 1963, 263, 933.

20. Yachnin, S. Biologic properties of polynucleotides. I. The anticomplementary activity of polynucleotides. J. clin. Invest. 1963, 42, 1947.

21. Yachnin, S., and J. M. Ruthenberg. The role of calcium in complement dependent hemolysis. Proc. Soc. exp. Biol. (N. Y.) 1964, 117, 179.

22. Yachnin, S. Unpublished data.

23. Yachnin, S., D. Rosenblum, and D. Chatman. Biologic properties of polynucleotides. VI. Further studies on the mechanism of complement inactivation by polyinosinic acid: the inactivation of the fourth component of complement. J. Immunol. 1964, 93, 549.

24. Lepow, I. H., L. Wurz, O. D. Ratnoff, and L. Pillemer. Studies on the mechanism of inactivation of human complement by plasmin and by antigen-antibody aggregates. I. The requirement for a factor resembling $\mathrm{C}^{\prime} 1$ and the role of $\mathrm{Ca}^{++}$. J. Immunol. 1954, 73, 146.

25. Christian, C. L. Studies of aggregated $\gamma$-globulin. 1. Sedimentation, electrophoretic and anticomplementary properties. J. Immunol. 1960, 84, 112.

26. Marcus, D. M. A study of the mechanism of the anticomplementary activity of $\gamma$-globulin. J. Immunol. 1960, 84, 273.

27. Linscott, W. D., and K. Nishioka. Components of guinea pig complement. II. Separation of serum fractions essential for immune hemolysis. J. exp. Med. 1963, 118, 795.

28. Rosen, F. Personal communication.

29. Jenkins, D. E., Jr., W. N. Christenson, and R. L. Engle, Jr. Erythrocyte complement coating in the acid hemolysin and thrombin tests of paroxysmal nocturnal hemoglobinuria (abstract). Blood 1962, 20, 788.

30. Müller-Eberhard, H. J., and U. Nilsson. Relation of a $\beta_{1}$-glycoprotein of human serum to the complement system. J. exp. med. 1960, 111, 217.

31. Müller-Eberhard, H. J., and C. E. Biro. Isolation and description of the fourth component of human complement. J. exp. Med. 1963, 118, 447.

32. Jenkins, D. E., Jr. Personal communication.

33. Hartman, R. C., and D. E. Jenkins, Jr. Analytical review: paroxysmal nocturnal hemoglobinuria. Blood, in press. 